This is an accepted manuscript of the article: López-Penabad, M., López-Andión, C., IglesiasCasal, A., \& Maside-Sanfiz, J. (2015). Securitization in Spain and the wealth effect for shareholders. International Review Of Economics \& Finance, 37, 308-323. http://dx.doi.org/10.1016/j.iref.2014.12.003.

(C) 2015. This manuscript version is made available under the CC-BY-NC-ND 4.0 license (http://creativecommons.org/licenses/by-nc-nd/4.0/)

\title{
SECURITIZATION IN SPAIN AND THE WEALTH EFFECT FOR SHAREHOLDERS
}

Ma Celia López-Penabad ${ }^{\mathrm{a}, *}$, Carmen López-Andión ${ }^{\mathrm{b}, 1}$,

Ana Iglesias-Casal ${ }^{\mathrm{b}, 2}$, Jose Manuel Maside-Sanfiz ${ }^{\mathrm{a}, 3}$

${ }^{\text {a }}$ Department of Finance and Accounting, University of Santiago de Compostela, Spain

${ }^{\mathrm{b}}$ Department of Quantitative Economics, University of Santiago de Compostela, Spain

KEYWORDS: wealth effect; event study; securitization; banking.

JEL classification: G28, G21 
SECURITIZATION IN SPAIN AND THE WEALTH EFFECT FOR SHAREHOLDERS

\begin{abstract}
This paper examines the relationship between securitization, the issuing bank's overall exposure to risk and the response of the shareholder. Spanish securitization transactions are analyzed using event study methodology which reveals that securitization drains banks' wealth, was most pernicious immediately prior to the subprime crisis and affects small and medium-sized banks most with respect to mortgage collateral transactions. The indirect effect of securitization on originator risk does not affect share value, while the direct effect gives a positive relationship. This effect becomes non-significant in the years prior to the crisis and the shareholders no longer perceive this risk transfer.
\end{abstract}




\section{INTRODUCTION}

Securitization really came to the fore in the USA in the 1990's, and reached its zenith between the years 2000 and 2007. Faced with a fall in the relative volume of individual customer deposits, securitization became an important source of financing which, at least in part, provided a means of driving the expansion in credit activity. However, the rapid growth in securitization led to a series of risks which were propagated by certain key countries and eventually infected larger regions as was the case of the UK in Europe, the result being the destabilization of the economy as a whole (Morales and Andreosso-O'Callaghan, 2014).

Various works ${ }^{1}$ have highlighted some of the aspects of securitization that might have been responsible for recent financial and economic instability: the lack of incentives on the part of the originators to control sufficiently high quality in collaterals, little transparency in securitization structures and lack of information with respect to the identification and localization of the real risks inherent in this type of operation.

The securitization market in Spain has been characterized by a number of phases, the most recent of which saw Spain issue more securitization by volume than any other country in continental Europe by 2010 (54.9 billion $€$ ), and only exceeded in volume by the United States $(1,276.7$ billion $€$ ) and the UK (102.6 billion $€$ ) world-wide. Securitization in Spain has become a key financial phenomenon which has significantly contributed to the capture of financing on the part of credit entities, both with respect to the economic and expansionary credit phases in capital markets and in the subsequent recessive phase, obtaining liquidity by means of operations carried out under the auspices of the Central European Bank.

The securitization market in Spain is characterised by its strict regulation and close links to the mortgage market. While Spanish legislation is similar to that of other countries, there are substantial differences when it comes to securitization. These differences are observable both with respect to the working securitization model and the relative of quality of the underlying assets.

\footnotetext{
${ }^{1}$ Keys et al. (2010); Purnanandam (2011); Calmes and Téoret (2010); Fahri and Tirole (2009); Douglas and Raghuram (2009); Arce et al. (2012).
} 
The former is characterised by simple structures and aims to finance the credit entity rather than transfer risk, the so-called originate-to-hold model. The latter, the quality of the underlying assets, is generally believed to be high in Spain, even during the crisis years. The Spanish banking model is traditional and based upon a close relationship between the entities and their clients. This ethos has permeated securitization and means that the originator continues to carry out the role of administrator in nearly all securitization operations. Further, in Spain, the rates of retention for the first losses tranche are much greater than in other countries. In fact, in almost all securitizations the originator retains all of the first losses.

This study sets out to empirically analyze the relationship between the securitization of credit risk, exposure to overall risk on the part of the issuing bank and the effects on the wealth of the banks' shareholders in the Spanish market between 1995 and 2010. We aim to clarify the nature of the effects caused by the securitization of credit risk in the Spanish market via an analysis of the wealth effects experienced by the shareholders of the originator entities. By so doing we hope to improve our understanding of, and rekindle confidence in the process of securitization itself.

The event analysis carried out demonstrates that the announcement of securitization transactions impacted negatively on the issuing bank's share price. This might be due to the high risk reinvestment strategy adopted by Spanish banks and the retention of the highest risk first loss tranche. The analysis that uses subsamples gives a negative effect for share prices for the 2005 to June 2007 period, an effect which is non-significant in the 1995-2004 and July 2007-2010 periods. Securitization is an important event for small entities because, as is shown, the negative impact on share prices is significant for them, as are the negative effects in the case of mortgage backed securitizations.

We believe that this work complements and enlarges upon other empirical studies in the field (Lockwood et al., 1996; Martínez-Solano et al. 2009; Thomas, 2001; Gasbarro et al., 2005; Franke and Krahnen, 2006; Hänsel and Krahnen, 2007; and Udhe et al. 2012), for various reasons.

First, the study is innovative because it looks at the Spanish securitization market and adopts a very broad time-frame, 1995 to 2010 while including a large number of originator entities. This 
allows the analysis to study the market and extract conclusions by referring to different stages or phases of activity, one of slow growth up until the end of the 1990's followed by a period of spectacular growth until mid 2007, followed by a phase of profound economic crisis. In addition, the peculiarities of the Spanish securitization market, in contrast with other markets (legislative differences, simple and traditional securitization structures, traditional banking model ${ }^{2}$ and the high level of retention in the first-loss tranche ${ }^{3}$ ) enables this work to reveal important aspects of the relationship between financial and market frictions and the way in which the originator is willing to assume risk. We divide the sample according to the size of the originator entity and type of collateral. Our results are in line with those obtained for other countries.

Second, in order to reveal the significance of the abnormal stock return, the analysis includes additional tests which, until now, have not been implemented in studies of securitization. These tests are the alternative proposed by Chen et al (2011) to the BMP test established by Boehmer et al (1991) and the cross-sectional variance-adjusted version of the $\mathrm{T}_{3}$ test developed by Corrado (1989).

Further, in the cross-sectional analysis we incorporate both the direct and indirect effects on aggregate returns. As far as we know, our study is the first that both proposes and applies a measurement of the direct and indirect effects of securitization on the risk to the originator and, specifically, on how this affects the price of the shares of the issuing entity.

The rest of the work is set out as follows: section two provides a review of the existing literature; there is then a description of the data base used and the methodology utilized, after which the results of the econometric analysis are given and interpreted. The final section includes the main conclusions.

\section{RELATED LITERATURE}

\footnotetext{
2 In this regard, the regulation of the mortgage market has played a key role in mortgage bonds (participaciones hipotecarias). This legislation establishes that the administration of mortgage loans must be kept in the hands of the original banking entity. The importance of the mortgage market in Spain, and the fact that this market first used securitization, has contributed to the dynamic via which the administration and custody of non-mortgage securitization loans are carried out by the original issuing entities.

3 Securitization is a mechanism that facilitates the stratification of credit risk. The bonds are issued in different series with a specific subordinate structure. In the lower part of this structure are the series containing the lowest credit quality products, the equity tranche, which is normally retained by the issuer in order to provide the required credit enhancement level to the higher tranches, "mezzanine" and "senior".
} 
Securitization is a financial operation that makes it possible to transform a series of illiquid assets into a series of bonds which are then placed in the market (securitization bonds) and are guaranteed by a series of predetermined payment flows. At the same time, securitization is a mechanism for transferring risk.

When an entity carries out securitization, its exposure to risk is affected both directly and indirectly. The direct effect refers to the amount of risk which is transferred to the market. Some studies indicate that there is a reduction in global risk when the tail risk in the senior tranches outweighs the default risk in the first loss tranches - hence there occurs a transfer of risk from the issuing entity to the investors - (Jiangli et al. 2007; Jiangli and Pritsker, 2008). Other studies show that the major part of the default risk remains in the first loss tranche, which is retained on the bank's balance sheet as a sign of credit quality for the investors (Riddiough 1997; DeMarzo 2005; Instefjord 2005). The Basilea I framework, which was in vigour until 2003, provided an incentive for the banks to transfer the loans which had the lowest levels of risk and maintain those with the highest levels in their portfolios within the first loss tranche. This would allow them to take advantage of the benefits of securitization in order to improve the status of their regulatory capital (Merton 1995; Calem and Lacour-Litle 2003); given that for Basilea I the capital requirements were lower than for Basilea II (Allen y Gale 2006).

The indirect effect of securitization on the risk of the issuing entity is determined by the strategy adopted by this entity in the reinvestment of the liquidity obtained from the securitization. This effect depends upon the investment policy adhered to and is defined by how the risk in the bank's portfolio is transformed (Leland 2007). In this sense, the reinvestment process might give rise to improved diversification on the entity's balance sheet if investment takes place in new assets which are largely uncorrelated to the rest of the assets within the portfolio (Greembaum and Thakor, 1987; Carlstrom and Samoluk, 1995; and Gorton and Pennachi, 1995). In contrast, the effect of securitization on the financial stability of the entity depends on the level of risk of the new assets which, in turn and to a large extent, is determined by the levels of competition in the market (Instefjord 2005). Hence, if the liquidity generated via the securitization process is used 
in order to increase the amount of total assets, or with the aim of repurchasing shares or paying a higher dividend, this might generate even greater leverage, and thus weaken the financial stability of the entity (Shin 2009; Leland 2007; Cebenoyan and Strahan, 2004).

We focus on how shareholders can anticipate the effects of the securitization of credit risk. By reviewing the relevant literature, it may be seen that the economic benefits derived from securitization certainly do exist. There is a plethora of reasons that lead the banks to carry out securitization. Three of the most important are as follows:

i. The volume of requisite regulatory capital is lower (Merton 1995)

ii. It serves to administer the bank's financing and liquidity (Greenbaum and Thakor, 1987; Rosenthal and Ocampo, 1988; and Leland, 2007)

iii. It reduces the bank's overall exposure to risk by specifying and diversifying the credit portfolio (Gorton and Pennacchi, 1995; Carlstrom and Samolyk, 1995; and Duffie, 2007). With respect to reasons $i$ and ii the authors describe two of the most widely accepted benefits of securitization, so there is a tacit assumption that shareholders can anticipate the announcement, and take advantage of a higher ex-post share price.

With respect to reason iii there is no real agreement with respect to the relationship between the exposure to overall risk experienced by the originator and the value for shareholders. Hence, there is a negative reaction in share prices to announcements of securitization if the shareholders anticipate that the originator retains the first loss tranche as a sign of quality for the investors. The wealth of bank shareholders is also likely to decrease if the shareholders expect a high risk reinvestment strategy. Reinvestment in low quality assets (e.g. granting higher risk loans) is more likely given that a change from the "originate to hold model" to "originate to distribute" might affect the banks' incentives to monitor and screen. Finally, a negative reaction in terms of share prices should be expected if the shareholders anticipate that the financing derived from the securitization will be utilized to rebalance the structure of the issuing bank's capital (e.g. via the repurchasing of its own stocks or by paying higher dividends) and thus creating even greater banking leverage. 
In contrast, a positive reaction in share prices is to be expected as a consequence of securitization when the shareholders anticipate that the tail risk in the senior and mezzanine tranches, which is transferred off balance sheet, exceeds the default risk of the first loss tranche. Similarly, the value for the bank shareholders is likely to increase if they expect the issuing bank to follow a conservative reinvestment strategy which results in greater diversification in its loans portfolio and a decrease in its rate of leverage. Hence, using funds to acquire new assets generates improved diversification in the bank's assets portfolio if the resultant total assets are less closely correlated after the securitization. Equally, the reinvestment of funds in assets that are free from risk or which carry a reduction in liabilities, increases creditworthiness and decreases leverage. Therefore, the real effect of the bank's overall exposure to risk depends on the way in which the risk contained in bank's assets portfolio is restructured (Krahnen and Wilde, 2006), which, in turn, is determined by the level of competition in the assets market (Instefjord, 2005).

One of the factors which influences how much risk banks are willing to take on board is the existence of financial friction within the markets. The literature suggests that the relationship between financial friction and the decision to take risks is positive (Osborne and Lee, 2001). It has been asserted that moral hazard and agency problems between bank managers and bank shareholders might generate incentives to assume risk, which would favour a climate of overinvestment on the part of the bank's management (Stulz, 1990; and Demirgüç-Kunt and Detragiache, 2002). Hence, financial frictions might lead to a lower perception of risk or an increase in risk tolerance on the part of the banks, resulting in greater financial fragility (Chortareas et al., 2011).

With respect to market frictions, it has come to light that certain banking market structures (and in particular certain competitive market structures) might not be neutral from the point of view of financial stability (Delis et al., 2008; and Chortareas et al., 2011). Greater competition in banking markets together with a greater availability of credit might result in a pronounced fall in profit margins. This would probably encourage banks to soften their lending standards and, in so doing, increase their exposure to credit risk in order to fulfil capital market expectations (Peydrò and 
Maddaloni, 2010). Studies such as those of Chen et al. (2011), Jiangli et al. (2007) and Casu et al. (2010) reveal that the retention of risk in securitization operations varies according to the type of underlying asset. There is evidence that there is a significant negative effect with regard to assuming risk when it is mortgage backed loans that are being securitized.

Empirical evidence as to the relationship between the securitization of credit risk and the shareholders' wealth effects is ambiguous. For example, Lockwood et al. (1996) for the US market, provide evidence that there are abnormal negative returns for bank stocks around the date of the announcement of a securitization. Their analysis reveals that the wealth effect generated by securitization activity depends upon the pre-event financial soundness of the issuing bank. Thomas (2001), who also looks at the U.S. market, found that this scenario had a negative impact on the stock price of the issuing bank. Hence, this particular study reveals that securitization transactions tend to create losses for the shareholders, particularly when the capital markets are in tension or crisis. In contrast, Gasbarro et al. (2005) (US market) found that the announcement of a securitization transaction positively affects the issuing bank's share prices. The evidence provided in this study further suggests that there are greater positive wealth effects for those banks with high financial leverage, low non-interest costs, and which issue securitization more frequently. Further, in contrast to the work of Lockwood et al. (1996) their study reveals that securitization provides greater shareholder value for the more highly leveraged entities. For the Spanish market, Martínez-Solano et al. (2009) show that there are significant, positive, abnormal profits on the day immediately after the announcement day and the reaction of the market is stronger when the announcements are made by banks with a higher proportion of equity in its capital structure and which are less profitable. Finally, Udhe et al. (2012) offer evidence of negative wealth effects for a sample of EU-15 plus Switzerland.

As stated above, the object of this work is to analyze the relationship between the securitization of credit risk, the exposure of the issuing bank to the overall risk and the response of the shareholder. By so doing it is hoped the analysis will help to clarify the connection between financial frictions, market frictions and the willingness of banks to assume risk. In the Spanish 
market, the predominant securitization model has been originate-to-hold ${ }^{4}$ and, in this case, there is only a real transfer of risk when the final loss within the portfolio exceeds those in the first loss tranche. Hence, it is to be expected that there will be a negative reaction in terms of share prices when there is an increase in the levels of risk for the issuing entities. However, it should not be forgotten that the reinvestment of the new funds might purchase assets which are less closely correlated to the originator's portfolio, thus improving diversification or, just the reverse, lower credit quality assets might be acquired. Therefore, securitization might have given rise to an increase in lower quality credit, particularly at the end of the credit boom. In addition to products of lower credit quality, securitization may well have helped to undermine the foundations of banking entities by increasing their levels of risk and reducing shareholder wealth.

\section{DATA AND EMPIRICAL METHODOLOGY}

\subsection{DATA AND SOURCES}

The data base used in this study is made up of 185 issues of mortgage-backed securities (MBS) and asset-backed securities (ABS) carried out in Spain between the years 1995 and July 2010. The data was obtained from the web page of the Comisión Nacional del Mercado de Valores (CNMV) (Securities and Exchange Commission), from the Spanish corporate loans market - The Association of Financial Asset Intermediaries (AIAF-initials in Spanish) -, and the existing Spanish assets securitization management companies' web pages. The analysis also used the daily stock market quotes at the close of trading for 14 of the banks ${ }^{5}$ that had been the originators in the issue of securitization. This information was obtained from the Spanish Stock Markets and Exchanges web (Bolsas y Mercados Españoles (BME) - in Spanish). The data base used in this analysis contains 25 banks that have participated as issuing banks. However, close-of-trading

\footnotetext{
${ }^{4}$ Among others, Fuentes (2007), Martín-Oliver and Saurina (2007), Catarineu and Pérez (2008) and Cardone, Samaniego and Trujillo (2010).

${ }^{5}$ The banks for whom viable stock market quotes were available were: Banco Español de Crédito, Banco Pastor, Bankinter, BBVA, Banco de Valencia, Banco Popular Español, Banco Sabadell, Banco Santander, Banco Guipuzcoano, Banco de Andalucía, Banco de Castilla, Banco de Galicia, Banco de Crédito Balear and Banco de Vasconia. Some of the Banks are quoted on the stock exchange according to the "Continuous Spanish Market" method, while some of the less liquid entities are aligned to the "Fixed System". This might place a certain limitation on the analysis.
} 
prices were only available for those entities that have been quoted on the Spanish Stock Exchange $^{6}$.

The daily close of trading prices for the Ibex-35 index were used as an indicator of a portfolio of market stocks for the period analyzed.

In addition, and as a means of better gauging the impact of the securitization of credit risk on bank shareholder value and, by doing, preventing any possible bias in the estimated results, securitization transactions are excluded if there were other types of relevant event during the event window. These events, which might have affected share prices, included: profit or dividend announcements, splits, announcements of share issues or the payment of dividends, mergers and suspended trading ${ }^{7}$. As a result, 23 securitization transactions were eliminated.

Table 1 (in the Appendix) shows the characteristics of the definitive database which contains 162 traditional securitizations with an average volume of 1,060 Million $€$, and a volume of 171,812 Million $€$, corresponding to 14 quoted issuing banks. The most active of the issuing banks were BBVA with 30 securitization issues and 58,947 Million $€$, followed by Banco Santander with 18 and 29,530 Million $€$ and Bankinter with 23 and 24,232 Million $€$. These three banks issued the highest volume of securitizations and, together with Banco Popular and Banco Español de Crédito were responsible for $55 \%$ of all mortgage-backed operations.

With regard to the distribution according to years, $56 \%$ of securitizations announcements occur in 2006, 2007 and 2008. The volume of securitization issued during these same years was even greater $(66.20 \%)$. In short, both the number and the size of the issues were greater during this period.

The distribution of the issues according to type of collateral reveals the relevance of mortgages in Spain since the presence of this kind of collateral was particularly strong during the period being analysed with the exception of the year 1996. Securitization using mortgage collateral

\footnotetext{
${ }^{6}$ Since the savings banks are not quoted on the stock exchange it is not possible to obtain an indicator as to how their securitization activity is affecting systematic risk, even though it is an important proportion of all securitization in Spain. However, given the characteristics of these entities, and that little of their activity takes place outside Spain, there are good reasons to believe that the return of these entities is similar to that of the quoted banks.

${ }^{7} \mathrm{We}$ did not take into account variations in the ratings of the issuing entities since the Spanish market is practically immune to these changes as Abad and Robles (2014) clearly demonstrate.
} 
represented $57 \%$ of securitization issues in Spain during the period. $39 \%$ of securitizations corresponded to collateral in business loans, securitizations which were concentrated in the period from 2006 to 2008. Consumer credit securitization made up the remaining $18 \%$. On looking at the monthly distribution we find that there were issues throughout the year, although there were fewer of these in August and January, and more in May, June, September and October.

We supplemented the data base with financial information for the originators obtained from Bankscope (Table 2 in Appendix).

\subsection{EMPIRICAL METHODOLOGY}

In line with Brown and Warner (1985), this analysis adopts standard event analysis to study the effect of securitization on the share value of the issuing bank. The aim of this approach was to gauge any reaction in share prices to announcements of securitization while at the same time taking into account abnormal stock returns on or around the date of the securitization. The abnormal return of a share $\left(A R_{i, t}\right)$ is held to be the difference between the observed stock return of the share $\left(R_{i, t}\right)$ and the expected return when it is assumed that there has been no further price sensitive event (which in our case means that there was no securitization announcement). In short, it is the prediction error obtained using the standard market model in order to estimate the reference or expected return. Said model is as follows:

$$
R_{i, t}=\beta_{0, i}+\beta_{1, i} R_{m, t}+\varepsilon_{i, t}(1)
$$

where $R_{i, t}$ and $R_{m, t}$ represent the daily returns on banks' stock i and the market portfolio $\mathrm{m}$ at a trading day $\mathrm{t}$, expressed in percentage points and obtained as a first difference of the logarithms of the prices of said stocks; $\varepsilon_{i, t}$ is the error term and $\beta_{\mathrm{i}}$ the coefficients of the regression. $\beta_{\mathrm{i}}$ are estimated for a 201 day period which end five days before the event (issue announcement date, $\mathrm{t}_{0}$ ). The event window takes in 11 trading days on and around the date $\mathrm{t}_{0}$ which takes in the interval $[-4,+6]$ 
In accordance with the financial literature, it is common to encounter clusters of volatility when analyzing daily returns on banks' stocks. Hence, in order to model the dynamic behaviour of the conditional variance of the error term, a GARCH $(1,1)$ is adopted

$$
\mathrm{h}_{\mathrm{i}, \mathrm{t}}=\alpha_{0, \mathrm{i}}+\alpha_{1, \mathrm{i}} \varepsilon_{\mathrm{i}, \mathrm{t}-1}^{2}+\alpha_{2, \mathrm{i}} \mathrm{h}_{\mathrm{i}, \mathrm{t}-1}
$$

where $\mathrm{h}_{\mathrm{i}, \mathrm{t}}=\operatorname{Var}\left(\varepsilon_{\mathrm{i}, \mathrm{t}} / \mathrm{I}_{\mathrm{t}-1}\right)$ and $\mathrm{I}_{\mathrm{t}-1}$ represents the information available at time $\mathrm{t}-1$.

This specification is deemed necessary given the results that are contained in Table 3, which indicate the stationarity and leptokurtic distribution of the daily returns and the existence of first order autocorrelation in their squares and absolute values. Other works such as those of MatínezSolano et al, 2009 and Uhde et al, 2012 also incorporate volatility clusters. This procedure ensures that biased parametric and non-parametric tests and erroneous conclusions are avoided when testing the significance of abnormal returns.

Table 3. Descriptive statistics of bank stock returns

\begin{tabular}{|c|c|c|c|c|c|c|c|}
\hline Banks & $\mathrm{S}$ & $\mathrm{K}$ & $\mathrm{JB}$ & $\mathrm{ADF}$ & $\mathrm{Q}\left(\mathrm{rt}^{2}\right)$ & $\mathrm{Q}\left(\left|\mathrm{r}_{\mathrm{t}}\right|\right)$ & N. obs \\
\hline Banco de Andalucía & -0.4 & 24.3 & $65793.9 * * *$ & $-63.4 * * *$ & $176.5 * * *$ & $278.7 * * *$ & 3489 \\
\hline Banesto & -0.9 & 27.2 & $72779.8 * * *$ & $-56.4 * * *$ & $129.2 * * *$ & $319.0 * * *$ & 2977 \\
\hline Bankinter & 0.3 & 7.6 & $2525.5 * * *$ & $-50.7 * * *$ & $271.3 * * *$ & $227.1 * * *$ & 2752 \\
\hline$B B V A$ & 0.2 & 10.0 & $8157.9 * * *$ & $-58.5^{* * *}$ & $185.7 * * *$ & $367.9 * * *$ & 3972 \\
\hline Banco de Castilla & 0.3 & 13.2 & $11832.0 * * *$ & $-34.1 * * *$ & $318.8 * * *$ & $225.7 * * *$ & 2727 \\
\hline Banco de Crédito Balear & 0.2 & 18.5 & $27042.3 * * *$ & $-30.9 * * *$ & $37.5 * * *$ & $97.5^{* * *}$ & 2702 \\
\hline Banco de Galicia & 0.4 & 14.1 & $13895.8 * * *$ & $-35.4 * * *$ & $232.1 * * *$ & $266.0 * * *$ & 2700 \\
\hline Banco Guipuzcoano & 0.8 & 12.2 & $10802.6 * * *$ & $-58.6 * * *$ & $122.0 * * *$ & $240.5 * * *$ & 2975 \\
\hline Banco Pastor & 0.3 & 8.6 & $3707.8 * * *$ & $-51.2 * * *$ & $81.1 * * *$ & $147.8 * * *$ & 2765 \\
\hline Banco Popular Español & 0.1 & 10.5 & $7522.4 * * *$ & $-55.0 * * *$ & $92.4 * * *$ & $228.8 * * *$ & 3213 \\
\hline Banco Sabadell & 0.6 & 13.4 & $9045.1 * * *$ & $-42.0 * * *$ & $55.8 * * *$ & $44.5 * * *$ & 1981 \\
\hline Banco Santander & 0.4 & 13.7 & $16607.7 * * *$ & $-59.1 * * *$ & $299.0 * * *$ & $524.5 * * *$ & 3462 \\
\hline Banco de Valencia & 0.5 & 9.3 & $2976.4 * * *$ & $-43.7 * * *$ & $89.7 * * *$ & $161.2 * * *$ & 1733 \\
\hline Banco de Vasconia & 0.2 & 16.6 & $20328.8 * * *$ & $-58.3 * * *$ & $298.5 * * *$ & $279.5 * * *$ & 2654 \\
\hline
\end{tabular}

The mean and conditional variance (equations 1 and 2) are jointly estimated via maximum likelihood and a normal distribution of the error term, $\varepsilon_{i, t}$, is assumed.

Table 4. Garch Effects

\begin{tabular}{ccc}
\hline $\begin{array}{c}\text { Median estimate } \\
(n=162)\end{array}$ & $\begin{array}{r}\text { Significant coefficients at the 5\% level } \\
\text { (percentage) }\end{array}$ \\
\hline$\alpha_{0}$ & 0,19 & $56 \%$
\end{tabular}




\begin{tabular}{lcc}
$\alpha_{1}$ & 0,22 & $82,7 \%$ \\
$\alpha_{2}$ & 0,61 & $74 \%$ \\
\hline Note: The model estimated by maximum likelihood is $\mathrm{R}_{\mathrm{i}, \mathrm{t}}=\beta_{0, \mathrm{i}}+\beta_{1, \mathrm{i}} \mathrm{R}_{\mathrm{m}, \mathrm{t}}+\varepsilon_{\mathrm{i}, \mathrm{t}}$ \\
with $\mathrm{h}_{\mathrm{i}, \mathrm{t}}=\alpha_{0, \mathrm{i}}+\alpha_{1, \mathrm{i}} \varepsilon_{\mathrm{i}, \mathrm{t}-1}^{2}+\alpha_{2, \mathrm{i}} \mathrm{h}_{\mathrm{i}, \mathrm{t}-1}$ assuming a normal distribution. We applied \\
the Wilcoxon signed rank test to medians of estimated coefficients following a \\
GARCH (1,1) process. A median that what significantly distinct from zero was \\
obtained.
\end{tabular}

As shown in Table 4, a high percentage of the $\operatorname{GARCH}(1,1)$ equation coefficients are statistically significant, which confirms the need for the modelling. Abnormal returns are calculated for each of the $\mathrm{N}$ securitizations, from this estimation as follows:

$$
A R_{i, t}=R_{i, t}-\hat{\beta}_{0, i}-\hat{\beta}_{1, i} R_{m, t}
$$

Average abnormal returns on day $\mathrm{t}$ would be

$$
\overline{A R}_{t}=\frac{1}{N} \sum_{i=1}^{N} A R_{i, t}
$$

Assuming that the abnormal returns of the shares are identically and independently distributed, the $\overline{A R}_{t}$ will be normally distributed.

The cumulative average abnormal returns for the interval $\left(t_{1}, t_{2}\right)$ is

$$
\overline{C A R}\left(t_{1}, t_{2}\right)=\sum_{t=t_{1}}^{t_{2}} \overline{A R}_{t}
$$

where $\left(t_{1}, t_{2}\right)$ is any interval that belongs to the event window.

In order to check the statistical significance of abnormal daily returns different types of parametric and non-parametric tests may be used. For parametric tests there are different kinds of testing procedures and this analysis uses two. The statistical significance tests used are the standardized cross-sectional test developed by Boehmer et al. (1991) (hereafter BMP). This test takes into account the possible cross-sectional heteroskedasticity and increases in the variance of abnormal stock returns during the event window, and a variant of the same test used by Chen et al. (2011) (hereafter $B M P$ alt.). The $B M P$ alt. test involves generating the standardized abnormal return by dividing the abnormal return by the standard error for the regression in the estimation period. For non-parametric analysis, both versions of the test developed by Corrado (1989) are used; the simple version - the $T_{3}$ test - and the cross-sectional variance-adjusted version $-T_{3}$ adj. testBoth tests are consistent with respect to non-normality since they fail to establish a supposition 
in connection with the distribution of the returns, which means that they are valid for small sample sizes.

Testing the significance of cumulated abnormal returns, in line with the work of Campbell et al. (2010) and Chen et al. (2011), the BMP test ${ }^{8}$ and the alternative Corrado $T_{3}$ test are used ${ }^{9}$.

The exogenous choice of the 11 day event window $[-4 ;+6]^{10}$ is arbitrary given that there is an assumption that the reaction in share prices to the announcement of securitization totally reflects how the securitization impacts on the value of the shares without bias within these 11 trading days. Nevertheless, it should not be completely ruled out that the 11 day period might accurately capture the information revealed in a securitization transaction. Therefore, since the market response might be incomplete or biased, we analyze the robustness of the result by estimating the cumulative abnormal return for various additional event windows $[-4,+3],[-4,+1],[-1,+6],[0,+6]$, $[+1,+6]$ and $[+2,+3]$

\section{RESULTS}

The results for the whole of the sample, both with respect to each of the individual days for the event window and for the cumulative abnormal return, are given in Table 5. The data refers to an 11 day trading window of $[-4,+6]$ on or around the date $t_{0}$ of the securitization announcement ${ }^{11}$; the index used was the Ibex-35.

The results reflect that Spanish originating bank share prices react negatively to the announcement of securitization. This response is neither prior to nor immediately after the announcement, but occurs on day +2 , as shown in 3 of the 4 tests that have been applied. The average of the abnormal returns for this day is -0.2507 .

Table 5. Wealth Effects around the Announcement Day

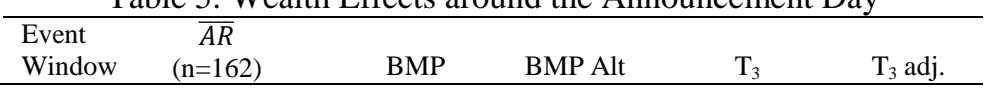

\footnotetext{
${ }^{8}$ Additionally, we have calculated the $\mathrm{t}_{\mathrm{AB}}$ test put forward by Kolari and Pynnönen (2010) both for the ARs and the CARs. This test is a variant of the BMP test that aims to take into account the cross-sectional correlation of the abnormal returns and the volatility induced by the event. The significance of the ARs and CARs is the same as for the cases tested using BMP.

${ }^{9}$ These tests which are applied to different days are dependent by construction. However, the effect of ignoring the dependence should be negligible for short event windows. So these tests applied to multiple day windows make the assumption that the daily returns are independent.

${ }^{10}$ The analysis has been carried out for other windows of a different length $[-5,+5]$ and $[-6,+4]$. The results will be made available to those interested.

${ }^{11}$ The results for other alternative windows are similar to those presented for the $[-4,+6]$ window.
} 


\begin{tabular}{|c|c|c|c|c|c|}
\hline-4 & 0.0118 & -0.8803 & -0.8831 & $-1.8756^{*}$ & $-1.8441^{*}$ \\
\hline-3 & -0.0736 & -1.1854 & -1.1891 & -1.3270 & -1.4286 \\
\hline-2 & 0.0594 & 1.1022 & 1.1042 & 1.0960 & 1.0468 \\
\hline-1 & -0.0150 & -0.2546 & -0.2655 & 0.1050 & 0.1655 \\
\hline 0 & -0.0183 & -0.6734 & -0.6608 & -0.3892 & -0.3879 \\
\hline+1 & -0.0528 & -0.6311 & -0.6403 & -0.3175 & -0.4409 \\
\hline+2 & -0.2507 & $-1.9903^{* *}$ & $-1.9984 * *$ & -1.5420 & $-1.6748 *$ \\
\hline+3 & -0.0351 & -0.3063 & -0.3007 & -0.7389 & -0.7304 \\
\hline+4 & -0.0273 & -0.0513 & -0.0594 & -0.1470 & -0.1457 \\
\hline+5 & -0.1589 & -1.2367 & -1.2468 & -0.5844 & -0.6371 \\
\hline \multirow[t]{2}{*}{+6} & -0.1375 & -1.1017 & -1.1078 & -1.4617 & -1.4292 \\
\hline & $\overline{C A R}$ & BMP & BMP Alt & $\mathrm{T}_{3}$ & \\
\hline$[-4,+6]$ & $-0,6980$ & $-2,0903 * *$ & $-2,0903 * *$ & $-2,1656^{* *} *$ & \\
\hline$[-4,+3]$ & $-0,3743$ & $-1,7152 *$ & $-1,7153 *$ & $-1,7639 *$ & \\
\hline$[-4,+1]$ & $-0,0885$ & $-1,0178$ & $-1,0178$ & $-1,1057$ & \\
\hline$[-1,+6]$ & $-0,6956$ & $-2,0037 * *$ & $-2,0037 * *$ & $-1,7945^{*}$ & \\
\hline$[0,+6]$ & $-0,6806$ & $-2,0962 * *$ & $-2,0963 * *$ & $-1,9581 *$ & \\
\hline$[+1,+6]$ & $-0,6623$ & $-1,9379 *$ & $-1,9379 *$ & $-1,9561 *$ & \\
\hline$[+2,+3]$ & $-0,2858$ & $-1,6852^{*}$ & $-1,6852 *$ & $-1,6128$ & \\
\hline
\end{tabular}

On analyzing the mean of cumulative abnormal returns for different windows, it is found that, for window $[-4,+1]$, none of the tests applied confirm the significance of an adverse effect on prices. However, the rest of the windows chosen and shown in Table 5 confirm the significance of the negative effect on prices.

These results for the average of the cumulative abnormal returns reinforce those obtained for day +2 and confirm the inexistence of a negative effect prior to day +2 indicating the significance of said effect when the day +2 is introduced into the window. The average of the cumulative abnormal returns for the $[-4,+6]$ window is -0.6980 whilst for window $[-1,+6]$ the figure is 0.6956; indicating that this latter window captures practically the whole of the effect.

These results are consistent with other findings obtained by Lockwood et al. (1996), Thomas (2001) and Udhe et al. (2012) but differ from the results obtained in the only study that looks at the Spanish market which finds that there is a positive relationship that is detectable on the day following the securitization announcement. The empirical results show that bank shareholders cannot foresee a decrease in the Spanish originating banks' overall exposure to risk as a result of the securitization of credit risk. With respect to theoretical arguments, the results suggest that the banks used in our sample managed to maintain most of the default risk within the first losses tranche and, in so doing, were able to transfer the smallest part of the credit risk off balance sheet 
(direct effect). Spanish banks use this securitization strategy because, by maintaining the highest risk first losses tranche this is normally perceived by potential investors as a sign of quality.

In addition to the effects that the direct impact of securitization announcements have on banks' overall exposure to risk, a negative reaction might also be explained by the issuing bank's investment policy and the decisions taken with respect to the structure of capital that results from securitization (indirect effect). In this sense, shareholders might expect a heavy risk reinvestment strategy and an ex-post redistribution of the capital structure that leads to lower creditworthiness for Spanish banks and an increase in the rate of bank leverage.

In an attempt to clarify the origin of this negative wealth effect for the shareholders of the originator entities, we first carried out regressions for different subsamples and then realized a cross sectional analysis of market.

\subsection{Subsamples}

The sample was divided according to the type of transaction, type of collateral and the size of the issuing entity. In order to isolate the period of economic crisis and its effects, the sample was also divided into two periods; from 1995 to June 2007 and July 2007 to 2010. In addition, the 1995 to 2007 period was subdivided: 1995 to 2004 and 2005 to June 2007. This was the first time a division into subsamples has been carried out for the Spanish market.

\subsubsection{Subsamples: 1995 to June 2007 and July 2007 to 2010}

On introducing the (1995 to June 2007) pre-crisis subsample and the (July 2007 to 2010) crisis subsample, Table 6 reveals that the negative effects on share prices are concentrated in the period prior to the crisis. The table also reveals that, subsequently, the negative effect is non-significant. This shows that there might be a return to lower risk transactions using traditional structures during the crisis period. It would seem therefore, that there was an attempt to reduce the risk inherent in the type of issues which, during the boom period for securitization, led to such 
complexity that even the foremost market analysts were unable to gauge the reach of these transactions.

In addition to the +2 window, the average of the abnormal returns is significant for other one-day windows $(-4,-3$ and +6$)$. On taking into account the cumulative abnormal returns, the cumulative effect in the $[-4,+1]$ window is not significant and this confirms that the individual effect of the previous days ( -4 and -3$)$ is offset by those that follow.

This result provides empirical evidence that the wealth effects arising from securitization activity in Spain depend on the time frame used both before and during the crisis. These results coincide with those obtained by Thomas (2001) for the American bank market.

Table 6. Wealth Effects around the Announcement Day: Pre-crisis and Crisis

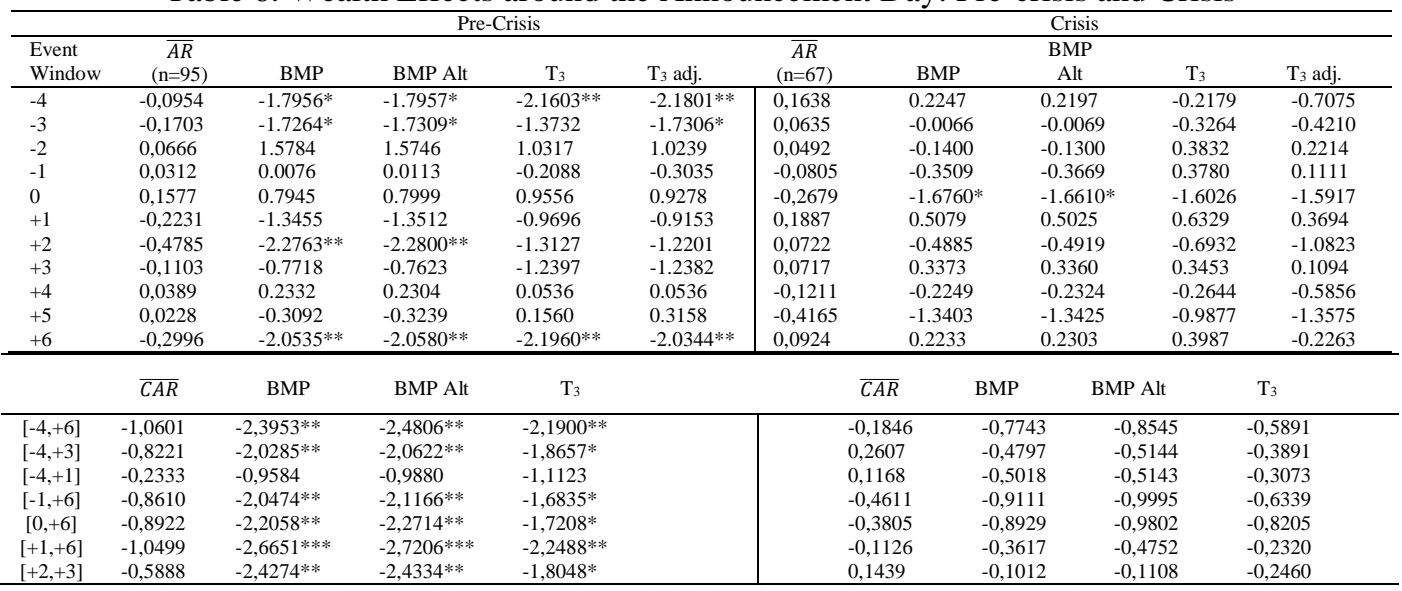

$* * *, * *, *$ indicates the significance of the tests with a probability of error of $1 \%, 5 \%$ and $10 \%$. The tests used are the parametric test proposed by Boehmer et al. (1991) and its alternative version (BMP and BMP Alt), and non-parametric tests proposed by Corrado and Zivney (1992) $\left(\mathrm{T}_{3}\right.$ and $\mathrm{T}_{3}$ adj.)

The considerable length of the pre-crisis period combined with the intense growth in securitization in Spain between 2005 and 2007 has led us to subdivide this period into two: 1995 to 2004 and 2005 to June 2007. Table 7 provides the results of these subsamples and confirms the presence of a significant negative wealth effect in the final period ${ }^{12}$. Therefore, shareholders would have been able to take advantage of the learning curve during the period of the sample (and in particular the final 2 years), thus making it possible to better take advantage of the impact of structured financial instruments and their inherent risk. If these assertions are correct, the negative response in share prices to securitization immediately prior to the sub-prime crisis in mid-2007, might have been a

\footnotetext{
${ }^{12}$ It is interesting to note, as in this case, the significant negative wealth effect occurs on day +1 and that the $[+2,+3]$ window is not significant, in contrast to the rest of the sub-samples with significant negative wealth effects.
} 
consequence of growing uncertainty among shareholders with respect to the real impact of the securitization on the originator banks' overall risk exposure.

Table 7. Wealth Effects around the Announcement Day: 1995 to 2004 and 2005 to June 2007

\begin{tabular}{|c|c|c|c|c|c|c|c|c|c|c|}
\hline \multirow[b]{2}{*}{ Event Window } & \multicolumn{5}{|c|}{1995 to 2004} & \multicolumn{5}{|c|}{2005 to June 2007} \\
\hline & $\begin{array}{c}\overline{A R} \\
(\mathrm{n}=45)\end{array}$ & BMP & BMP Alt & $\mathrm{T}_{3}$ & $\mathrm{~T}_{3}$ adj. & $\begin{array}{c}\overline{A R} \\
(\mathrm{n}=50)\end{array}$ & BMP & $\begin{array}{c}\text { BMP } \\
\text { Alt }\end{array}$ & $T_{3}$ & $\mathrm{~T}_{3}$ adj. \\
\hline-4 & 0,1591 & $-0,0567$ & $-0,0577$ & $-0,3490$ & $-0,3075$ & $-0,3244$ & $-2,5414 * *$ & $-2,5315^{\text {*** }}$ & $-2,6938 * * *$ & $-2,7763^{* * * * *}$ \\
\hline-3 & $-0,2476$ & $-1,6320$ & $-1,6365$ & $-0,9901$ & $-1,2103$ & $-0,1008$ & $-0,8643$ & $-0,8665$ & -0.9446 & $-1,1948$ \\
\hline-2 & $-0,0757$ & 0,6905 & 0,6865 & 0,1258 & 0,1652 & 0,1947 & 1,5956 & 1,5945 & 1,3272 & 1,2297 \\
\hline-1 & 0,0101 & $\begin{array}{l}-0,0696 \\
-0,0\end{array}$ & $\begin{array}{l}-0,0684 \\
-0,3\end{array}$ & $-0,2527$ & $-0,2987$ & 0,0501 & 0,0797 & 0,0836 & $-0,0415$ & $-0,0809$ \\
\hline 0 & 0,1674 & 0,3851 & 0,3843 & 0,9332 & 0,8526 & 0,1490 & 0,7113 & 0,7188 & 0,4132 & 0,4373 \\
\hline+1 & $-0,1635$ & $-0,2582$ & $-0,2581$ & 0,6488 & 0,5196 & $-0,2768$ & $-1,7829^{*}$ & $-1,7922^{*}$ & $-2,0138 * *$ & $-2,0160^{* * *}$ \\
\hline+2 & $-0,6609$ & $-1,6256$ & $-1,6271$ & $-1,2461$ & $-1,1111$ & $-0,3143$ & $-1,6246$ & $-1,6280$ & $-0,6035$ & $-0,6386$ \\
\hline+3 & $-0,2523$ & $-1,1184$ & $-1,1082$ & $-0,4125$ & $-0,4038$ & 0,0174 & $-0,1130$ & $-0,1088$ & $-1,3338$ & $-1,1143$ \\
\hline+4 & $-0,1418$ & $-0,6565$ & $-0,6560$ & $-0,8347$ & $-0,7758$ & 0,2015 & 1,0244 & 1,0188 & 0,9096 & 0,8638 \\
\hline+5 & 0,1282 & 0,1083 & 0,1010 & 0,5131 & 0,5674 & $-0,0722$ & $-0,5398$ & $\begin{array}{l}-0,5510 \\
-10\end{array}$ & $-0,2930$ & $-0,1334$ \\
\hline \multirow[t]{2}{*}{+6} & $\begin{array}{r}-0,3135 \\
\end{array}$ & $-1,0764$ & $\begin{array}{r}-1,0780 \\
\end{array}$ & $-0,9376$ & $-1,1510$ & $-0,2871$ & $-1,7468^{*}$ & $-1,7509^{*}$ & $-2,1559 * *$ & $-1,9430^{*}$ \\
\hline & $\overline{C A R}$ & BMP & BMP Alt & $\mathrm{T}_{3}$ & & & $\overline{C A R}$ & BMP & BMP Alt & $\mathrm{T}_{3}$ \\
\hline$[-4,+6]$ & $-1,3904$ & $-1,5396$ & $-1,5961$ & $-0,8448$ & & & $-0,7628$ & $-1,8307^{*}$ & $-1,8912^{*}$ & $-2,2401^{* *}$ \\
\hline$[-4,+3]$ & $-1,0633$ & $-1,1587$ & $-1,1780$ & $-0,5454$ & & & $-0,6051$ & $-1,8015^{*}$ & $-1,8368^{*}$ & $-2,0826^{* * *}$ \\
\hline$[-4,+1]$ & $-0,1501$ & $-0,2405$ & $-0,2576$ & 0,0473 & & & $-0,3082$ & $\begin{array}{l}-1,1488 \\
-1,10\end{array}$ & $-1,1848$ & $-1,6139$ \\
\hline$\left[\begin{array}{l}{[-1,+6]} \\
{[-1,+6]}\end{array}\right.$ & $-1,2262$ & $-1,5635$ & $-1,6069$ & $-0,5616$ & & & $-0,5323$ & $\begin{array}{l}-1,100 \\
-1,3313 \\
\end{array}$ & $\begin{array}{l}-1,1,3808 \\
-1,3898\end{array}$ & $\begin{array}{l}-1,8097^{*} \\
-\end{array}$ \\
\hline $\begin{array}{l}{[1-,+6]} \\
{[0,+6]}\end{array}$ & $\begin{array}{l}-1,202 \\
-1,2363\end{array}$ & $\begin{array}{l}-1,7030 * \\
-1,7047 *\end{array}$ & $\begin{array}{l}-1,0009 * \\
-1,7315^{*}\end{array}$ & $\begin{array}{l}-0,510 \\
-0,5049\end{array}$ & & & $\begin{array}{l}-0,5825 \\
-0,5825\end{array}$ & $\begin{array}{l}-1,0313 \\
-1,4258\end{array}$ & $\begin{array}{l}-1,5080 \\
-1,4929\end{array}$ & $\begin{array}{l}-1,0189^{*} \\
-1,96\end{array}$ \\
\hline$\left[\begin{array}{l}{[0,+0]} \\
{[+1,+6]}\end{array}\right.$ & $-1,4037$ & $-2,2210^{* * *}$ & $-2,2234 * *$ & $-0,9263$ & & & $-0,7314$ & $-1,6734^{*}$ & $-1,7384 *$ & $-2,2414 * *$ \\
\hline $\begin{array}{l}1+1,+6] \\
{[+2,+3]}\end{array}$ & $\begin{array}{l}-1,4017 \\
-0,9132 \\
\end{array}$ & $-2,2831 * *$ & $\begin{array}{l}-2,2859 * * \\
-2,225 *\end{array}$ & $\begin{array}{l}-0,963 \\
-1,1728 \\
\end{array}$ & & & $-0,2969$ & $-1,1638$ & $-1,1695$ & $-1,3698$ \\
\hline
\end{tabular}

\subsubsection{Subsamples: Small and large banks}

Two specific subsamples are created to control for the size of the bank. Small and medium sized banks are deemed to be those that have a total volume of assets which is less than or equal to 150 Billion $€$ and the large banks over 150 Billion $€$. The announcement of a securitization might be an important event for small and medium sized institutions but insignificant for large banks.

On effecting this division, we find that the average estimated cumulative abnormal returns are only negative and significant for the small and medium sized banks. The securitization of credit risk might be capable of affecting the share prices of smaller banks but not those of large entities.

As with the whole of the sample, the average cumulative abnormal returns in the $[-4,+1]$ interval is not statistically significant whereas those for the $[-1,+6]$ interval capture the greatest effect.

Table 8. Wealth Effects around the Announcement Day: Small and Large Banks

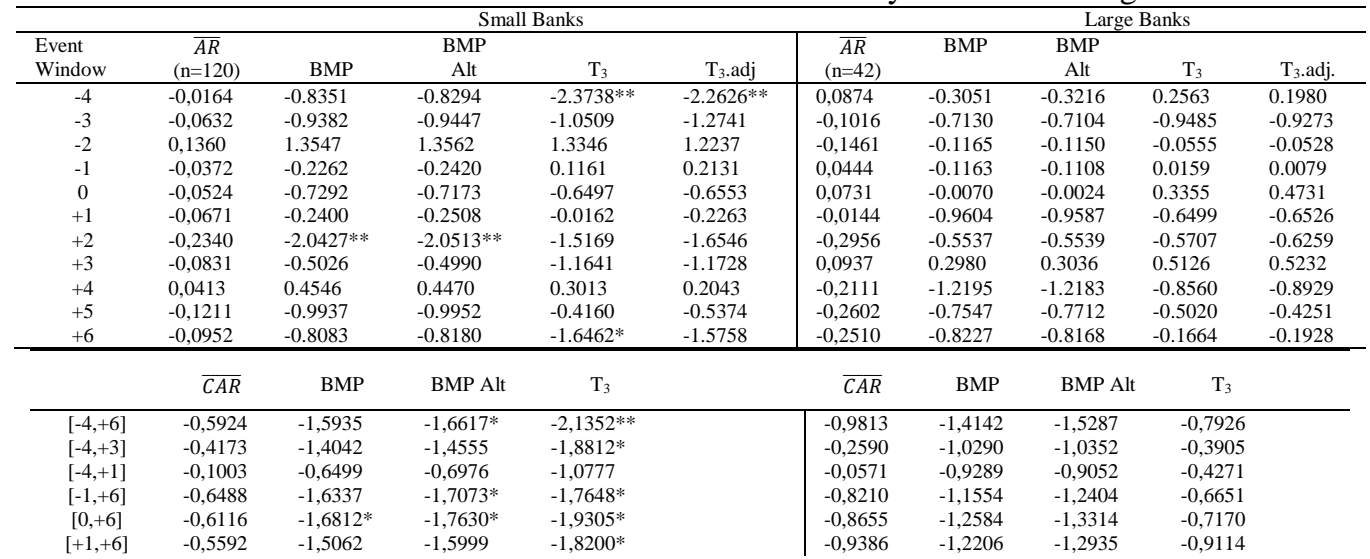


\begin{tabular}{ccccc|cccc}
{$[+2,+3$} & $-0,3171$ & $-1,8757 *$ & $-1,8828 *$ & $-1,8957 *$ & $-0,2019$ & $-0,2425$ & $-0,2486$ & $-0,0411$
\end{tabular} parametric test proposed by Boehmer et al. (1991) and its alternative version (BMP and BMP Alt), and non-parametric tests proposed by Corrado and Zivney (1992) $\left(\mathrm{T}_{3}\right.$ and $\mathrm{T}_{3}$ adj.)

\subsubsection{Subsamples: according to underlying asset; mortgages, business loans and consumer credit}

We analyze the impact of different types of underlying assets since the way in which bank share prices vary in response to securitization might be conditioned by the differences in nature of the risk in the reference portfolio and the residual loans portfolio (e.g. the degree of diversification, granularity and counterparty risk).

As shown in Table 9, there is no unanimous agreement in the test results capable of affirming that, for individual days, there was a significant negative effect. In the case of cumulative abnormal returns, only the mortgage securitizations produce a significant negative effect for those windows that include the +2 day. These results lead to the conclusion that the impact of the underlying asset is conditioned by the difference between its risk and the credit risk in the residual loans portfolio. Mortgage loans make for highly granular portfolios which are characterised by a lack of diversification (Catarineu, Pérez, 2008). Therefore, a negative response in terms of share prices confirms the results obtained in this study given that the originator banks can transfer lower risk tranches whilst maintaining those that are riskier in the loans portfolio.

Our results coincide with those of Chen et al. (2008) and Casu et al. (2011) who provide evidence that securitization has a negative impact on bank risk taking. They reveal that what exclusively determines this negative relationship is the securitization of mortgage loans and not by any other type of assets. They suggest that the net impact of securitization on originator banks and the way in which they approach risk taking might depend on the structure of the transaction and the fact that the securitization is used principally as yet another source of financing rather than an instrument of risk management. 
Table 9. Wealth Effects on or around the Announcement Day: mortgages, business and consumer loans

\begin{tabular}{|c|c|c|c|c|c|c|c|c|c|c|c|c|c|c|c|}
\hline \multirow[b]{2}{*}{$\begin{array}{l}\text { Event } \\
\text { Window }\end{array}$} & \multicolumn{5}{|c|}{ Mortgages } & \multicolumn{5}{|c|}{ Business Loans } & \multicolumn{5}{|c|}{ Consumer Credit } \\
\hline & $\begin{array}{c}\overline{A R} \\
(\mathrm{n}=69)\end{array}$ & BMP & BMP Alt & $T_{3}$ & $\mathrm{~T}_{\text {3adj. }}$ & $\begin{array}{c}\overline{A R} \\
(\mathrm{n}=63)\end{array}$ & BMP & BMP Alt & $\mathrm{T}_{3}$ & $\mathrm{~T}_{\text {3adj. }}$ & $\begin{array}{c}\overline{A R} \\
(\mathrm{n}=30)\end{array}$ & BMP & BMP Alt & $\mathrm{T}_{3}$ & $\mathrm{~T}_{\text {3adj. }}$ \\
\hline-4 & 0,2603 & 0.3650 & 0.3522 & -1.0513 & -0.5300 & $-0,1911$ & -1.4387 & -1.4245 & $-1.8158^{*}$ & $-1.7794 *$ & $-0,1335$ & -0.9432 & -0.9435 & -0.1406 & 0.1351 \\
\hline-3 & $-0,0906$ & -0.4809 & -0.4809 & -0.5994 & -0.5782 & $-0,0002$ & -0.4955 & -0.5002 & -0.8887 & -0.7563 & $-0,1890$ & $-1.7396^{*}$ & $-1.7414 *$ & -0.8711 & -0.6191 \\
\hline-2 & 0,1740 & $1.6959 *$ & $1.6933^{*}$ & 1.5902 & 1.6006 & 0,0121 & 0.0623 & 0.0664 & -0.0084 & -0.1056 & $-0,1046$ & -0.1556 & -0.1529 & 0.3915 & 0.0359 \\
\hline-1 & $-0,1878$ & -0.7266 & -0.7368 & -0.9176 & -0.5894 & 0,0034 & -0.5130 & -0.5153 & -0.2626 & -0.2552 & 0,3437 & 1.4701 & 1.4736 & $1.8140 *$ & $1.8876^{*}$ \\
\hline 0 & $-0,1136$ & -0.4916 & -0.4871 & -0.2578 & -0.2344 & 0,1693 & 0.0925 & 0.1075 & -0.0439 & -0.0607 & $-0,1932$ & -0.7485 & -0.7489 & -0.4687 & -0.7404 \\
\hline+1 & $-0,2520$ & -1.1890 & -1.1901 & -0.4487 & -0.4466 & 0,2573 & 1.0499 & 1.0355 & 0.4813 & 0.4381 & $-0,2459$ & -1.1616 & -1.1639 & -0.8353 & -0.9176 \\
\hline+2 & $-0,3478$ & -1.4427 & -1.4442 & -1.3483 & -1.2319 & $-0,1569$ & -1.3979 & -1.4078 & -0.4159 & -0.4793 & $-0,2245$ & -0.4369 & -0.4376 & -1.0751 & -1.4826 \\
\hline+3 & $-0,2630$ & -1.5013 & -1.4933 & -1.2804 & -1.2803 & 0,1966 & 0.9906 & 0.9919 & 0.6271 & 0.6827 & 0,0027 & -0.2592 & -0.2588 & -0.9097 & -0.7174 \\
\hline+4 & $-0,2107$ & -1.0867 & -1.1027 & -0.7458 & -0.4936 & 0,1504 & 0.8128 & 0.8173 & 0.0794 & 0.2063 & 0,0214 & -0.1092 & -0.1101 & 0.5238 & 0.4190 \\
\hline+5 & 0,0530 & -0.1430 & -0.1494 & 0.5230 & 0.5948 & $-0,3027$ & -0.9965 & -1.0077 & -0.7897 & -0.7745 & $-0,3445$ & -1.1441 & -1.1404 & -0.8188 & -1.0295 \\
\hline+6 & $-0,2611$ & -0.8693 & -0.8687 & -1.0725 & -0.9307 & $-0,1991$ & -1.1421 & -1.1510 & $-2.028 * *$ & $-1.7254 *$ & 0,2761 & 0.7030 & 0.7074 & 1.1248 & 1.0039 \\
\hline & $\overline{C A R}$ & BMP & BMP Alt & $\mathrm{T}_{3}$ & & $\overline{C A R}$ & BMP & BMP Alt & $\mathrm{T}_{3}$ & & $\overline{C A R}$ & BMP & BMP Alt & $\mathrm{T}_{3}$ & \\
\hline$[-4,+6]$ & $-1,2392$ & $-1,7220^{*}$ & $-1,7990 *$ & $-1,6911^{*}$ & & $-0,0609$ & $-0,8080$ & $-0,8882$ & $-1,5275$ & & $-0,7912$ & $-1,2028$ & $-1,7135^{*}$ & $-0,3815$ & \\
\hline$[-4,+3]$ & $-0,8205$ & $-1,3061$ & $-1,3266$ & $-1,5251$ & & 0,2905 & $-0,4992$ & $-0,5373$ & $-0,8227$ & & $-0,7443$ & $-1,3308$ & $-1,3520$ & $-0,7407$ & \\
\hline$[-4,+1]$ & $-0,2097$ & $-0,3553$ & $-0,3689$ & $-0,6877$ & & 0,2508 & $-0,5460$ & $-0,5525$ & $-1,0362$ & & $-0,5225$ & $-1,0982$ & $-1,1346$ & $-0,0450$ & \\
\hline$[-1,+6]$ & $-1,5829$ & $-2,551 * *$ & $-2,596 * * *$ & $-1,9616^{* * *}$ & & 0,1184 & $-0,3103$ & $-0,3980$ & $-0,8320$ & & $-0,3641$ & $-0,7615$ & $-0,7744$ & $-0,2281$ & \\
\hline$[0,+6]$ & $-1,3951$ & $-2,711 * * *$ & $-2,746 * * *$ & $-1,7502^{*}$ & & 0,1149 & $-0,1761$ & $-0,2904$ & $-0,7902$ & & $-0,7078$ & $-1,2736$ & $-1,2726$ & $-0,9294$ & \\
\hline$[+1,+6]$ & $-1,2815$ & $-2,844 * * *$ & $-2,869 * * *$ & $-1,7852^{*}$ & & $-0,0543$ & $-0,2079$ & $-0,3132$ & $-0,8355$ & & $-0,5146$ & $-0,9748$ & $-0,9752$ & $-0,8126$ & \\
\hline$[+2,+3]$ & $-0,6108$ & $-2,671 * * *$ & $-2,686 * * *$ & $-1,8588^{*}$ & & 0,0397 & $-0,1239$ & $-0,1265$ & 0,1493 & & $-0,2218$ & $-0,4946$ & $-0,4983$ & $-1,4035$ & \\
\hline
\end{tabular}

Alt), and non-parametric tests proposed by Corrado and Zivney (1992) ( $\mathrm{T}_{3}$ and $\mathrm{T}_{3}$ adj.) 


\subsection{Cross sectional analysis of market reaction}

The following cross-sectional analysis is carried out with the aim of clarifying the negative wealth effect.

As seen earlier, the Spanish market reacted negatively when banks announced they intended to securitize during the 1995 to 2010 period and, more specifically, for the 2005 to 2007 sub-period. This reaction might be because the investors anticipate that the securitization will have negative effects on the banking institution's solvency, profitability and liquidity. The market reaction could also depend on the extent of securitizations issued, the type of collateral, the precise moment the securitization is issued and, of course, on the modified risk to the entity derived from the direct and indirect effects of the securitization.

In order to take into account these effects on the risk we consider that the beta may be defined as:

$$
\beta_{i}=\rho_{i, m} \frac{\sigma_{i}}{\sigma_{m}}
$$

where $\rho_{\mathrm{i}, \mathrm{m}}$ is the lineal correlation coefficient between the asset's return and that of the market; and $\sigma_{\mathrm{i}}$ and $\sigma_{\mathrm{m}}$ the standard deviation of the return of the share and the market respectively. The securitization announcement might gradually change the beta coefficient during and after the event window, and said change might be broken down into a) the change in the correlation of the bank's return with that of the market portfolio $\left(\Delta \rho_{i, m}\right)$ and b) the change in the relative deviation of bank stock returns $\left(\Delta \frac{\sigma_{i}}{\sigma_{m}}\right)$.

Therefore, the systematic risk after the event may be expressed as:

$$
\beta_{i}^{1}=\rho_{i, m}^{1} \frac{\sigma_{i}^{1}}{\sigma_{m}^{1}}=\left(\rho_{i, m}^{0}+\Delta \rho_{i, m}\right) \frac{\sigma_{i}^{1}}{\sigma_{m}^{1}}=\beta_{i}^{0}+\Delta \beta_{i}
$$

where the periods immediately prior and subsequent to the event window are termed 0 and 1.

In order to take into account the change in beta, we moot the following model

$$
R_{i, t}=\beta_{i, 0}+\beta_{i, 1} R_{m, i, t}+\beta_{i, 2}\left(T_{1}-t\right)\left(t-T_{2}\right) D_{1, t} R_{m, i, t}+\beta_{i, 3}\left[\left(t-T_{1}\right) D_{1, t}+\left(T_{2}-T_{1}\right) D_{2, t}\right] R_{m, i, t}+\varepsilon_{i, t}
$$

where $R_{i, t}$ and $R_{m, t}$ are the previously defined values, $D_{1, t}$ and $D_{2, t}$ are the dummy variables. $D_{1, t}$ takes a value of 1 if $\mathrm{T}_{1} \leq \mathrm{t} \leq \mathrm{T}_{2}$, and $\mathrm{T}_{1}$ and $\mathrm{T}_{2}$ represent the start and end of the window, and takes a value of 0 otherwise. $D_{2, t}$ takes a value of 1 if $t>T_{2}$ and 0 for the rest; $t$ is the date of the event. 
The event window or interval used is $[-6,+6]$ days and the regressions are carried out using 241 data symmetrically moving around the event day ${ }^{13}$.

In order to carry out the breakdown of the change in the systematic risk, following Nijskens and Wagner (2011), it is necessary to normalize bank stock returns and market returns utilizing their respective standard deviations before and after the start of the event window. Once the return has been normalized, the modified model is estimated enabling us to estimate the change in $\rho_{i, m}$ :

$$
\tilde{R}_{i, t}=\rho_{i, 0}+\rho_{i, 1} \tilde{R}_{m, i, t}+\rho_{i, 2}\left(T_{1}-t\right)\left(t-T_{2}\right) D_{1, t} \tilde{R}_{m, i, t}+\rho_{i, 3}\left[\left(t-T_{1}\right) D_{1, t}+\left(T_{2}-T_{1}\right) D_{2, t}\right] \tilde{R}_{m, i, t}+\varepsilon_{i, t}
$$

$\tilde{R}_{m, i, t}$ and $\tilde{R}_{i, t}$ are daily normalized returns on the market portfolio and bank's stocks.

Finally, the change in the relative standard deviation is given by the following equation

$$
\Delta R E L \_S D=\Delta \frac{\sigma_{i}}{\sigma_{m}}=\frac{\sigma_{i}^{1}}{\sigma_{m}^{1}}-\frac{\sigma_{i}^{0}}{\sigma_{m}^{0}}=\frac{\beta_{i}^{0}+\Delta \beta_{i}}{\rho_{i, m}^{0}+\Delta \rho_{i, m}}-\frac{\beta_{i}^{0}}{\rho_{i, m}^{0}}(10)
$$

The variation in $\beta$ reflects the changes in the entity's systematic risk due to certain events such as the announcement of securitization. This is, therefore, an indicator of the effect of securitization as used in other studies such as those of Franke, Krahnen 2006; Hänsel, Krahnen 2007; Udhe, Michalak 2010 and Nijskens, Wagner 2011. The breakdown proposed allows us to quantify the direct effect by looking at the change in correlation between the share $\mathrm{i}$ and the market $\left(\Delta \rho_{i, m}\right)$. A positive coefficient should be expected if securitization succeeds in transferring risk to the market. In addition, we use the change in the Relative standard deviation ( $\triangle$ REL_SD) as a measure for the indirect effect. The volatility in the bank's portfolio is an indicator of the quality of same, hence the variation therein reflects the result of reinvestment of the flows of capital derived from securitization operations. An increase in volatility would have a negative effect on abnormal returns.

With regard to the characteristics of the banks being considered, we use the Z-Score ${ }^{14}$ ratio as a proxy of the banks' financial solvency (Michalak and Uhde, 2012, Battaglia and Mazzuca, 2011 and Ben Salah and Fedhila, 2012). The variable is determined as follows:

\footnotetext{
${ }^{13}[-6,+6]$ is the symmetrical window that most closely approximates to that used in our analysis.

${ }^{14}$ The Z-score indicates the number by which the standard deviation of the bank's asset returns has to drop for the entity to become insolvent. In short, it is a measure of how far a bank's asset returns must fall below their expected value before the institution's equity is depleted and the bank becomes insolvent.
} 


$$
S O L=Z-S c o r e \cong \frac{\mathrm{ROAA}+K}{\sigma}
$$

The ROAA is the return on average assets before taxes, $\mathrm{K}$ is the equity as a percentage of total assets and $\sigma$ is the standard deviation of the ROAA. We calculate the standard deviation of the ROAA for a rolling time window of three years. We expect a positive relationship between solvency and the CARs. The greater the Z-Score ratio the greater the margin between solvency and bankruptcy, hence it is logical to expect that increases in this ratio lead to increases in the CARs.

The rest of the variables included are the liquidity ratio (LIQ), and the volume of securitization issued for each of the financial entities and for each year (SVOL) ${ }^{15}$. It should be expected that these factors affect CARs positively and negatively respectively. It is possible that those entities that experience financial instability more readily rely upon securitization to extricate themselves from this uncertainty and thus we would expect a negative coefficient for SVOL. An increase in liquidity is a sign of financial health and so we would expect a positive relationship with the CARs.

Finally, in order to control for the type of collateral, we use the dummy variable DMORT that equals 1 for mortgage collaterals and 0 otherwise.

To analyze the factors that may explain the abnormal returns we estimate the following crosssectional model.

$$
\operatorname{CAR}_{(-1,6), i}=\alpha_{0}+\alpha_{1} L I Q_{i}+\alpha_{2} S O L_{i}+\alpha_{3} \Delta \rho_{i}+\alpha_{4} \Delta R E L_{-} S D_{i}+\alpha_{5} S V O L_{i}+\alpha_{6} D M O R T_{i}+\varepsilon_{i}
$$

The estimation method used is Least Squares with White standard errors in those equations in which heteroskedasticity is detected.

Table 10 shows the results of the estimations of different specifications of the equation (12) ${ }^{16}$. As explanatory variables regression (1) uses the CAR in the $[-1,+6]$ window for the whole of the

\footnotetext{
${ }^{15}$ Table 2 is given in the Appendix and gives all of the variables.

${ }^{16}$ Only the most relevant results are given, hence some of the variables given in table 2 do not appear. The bank's net interest margin and impaired loans, for example, do not obtain significant results and are not given here.
} 
sample ${ }^{17}$, liquidity (LIQ), solvency (SOL), the volume of securitization (SVOL), and the two variables that take in the direct $(\Delta \rho)$ and the indirect effects ( $\Delta$ REL_SD). It also includes the DMORT dummy variable which takes a value of 1 for mortgage collateral. The results show that only the $\Delta \rho$ coefficient is positive and significant, which confirms the importance of the direct effect derived from the announcements of securitization on share prices and, as such, confirms the transfer of risk to the market. The effect of liquidity and the volume of securitization are also significant. Liquidity has a positive influence whilst the volume of securitization has a negative influence whose importance is negligible. The mortgage dummy variable is also significant and negative which indicates the relevance of mortgage collateral on share values.

This result from regression 1 is maintained for regressions 2, 3 and 4 which progressively eliminate the solvency, liquidity and dummy mortgage variables, thus confirming the importance of the direct effect on share values and the non-significance of the indirect effect.

Reducing the sample to the January 2005 to June 2007, regression 6 incorporates liquidity and solvency as explanatory variables. Both give a positive, significant effect which indicates that increases in liquidity and solvency are reflected in increases in the CAR during this period. This same regression for the total period (Regression 5) shows that the effects of these two variables are non-significant. Similarly, Regression 7 shows that the direct effect of securitization, $\Delta \rho$, is non-significant, as is the indirect effect $\triangle \mathrm{REL} \_\mathrm{SD}$. This suggests that shareholders do not perceive a transfer of risk to the market as a consequence of securitization. Further, the reinvestment of the liquidity obtained and, more specifically, how this affects the bank's final portfolio (which potentially impacts on diversification), is either not perceived by the investor or not held to be of importance. That is, shareholders do not observe a transfer of risk and fail to appreciate any change in risk indirectly. Therefore, the risk remains in the originator entity and it is normal that the effect of securitization on the CARs was both negative and significant.

\footnotetext{
${ }^{17}$ In total, the sample contains 162 securitizations but when the variables that are relative to the banks' characteristics are included, the sample size is reduced because of a lack of data pertaining to the year of securitization.
} 
On considering the whole of the sample of securitizations it may be observed that only the direct effect is significant. This shows that, in those securitization operations in which there is perceived to be greater transfer of risk to the market, there is also a greater wealth effect, which might mean that, on average, this is non-significant in some of the sub-periods.

Our results substantially improve upon those of previous works in the field since they shed light on how the direct and indirect effects of securitization affect the issuing entity and the shareholders' perception of the changing value of their shares. Further, in contrast to the work of Martínez-Solano (2009), our results for the liquidity and solvency variables are significant and take the expected signs.

Table 10. Results of Cross-sectional analysis of cumulative abnormal returns

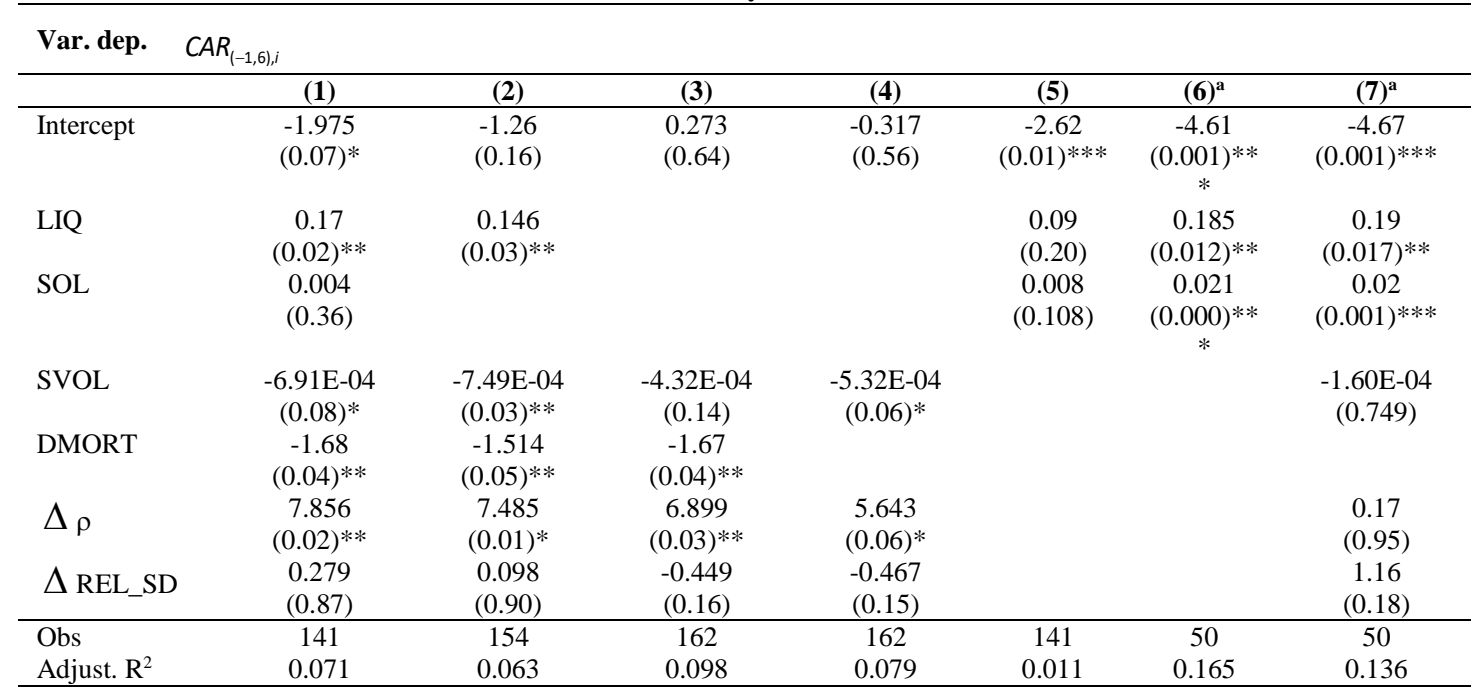

Equations estimated for Least Squares using the White correction for the standard errors in those cases in which there is heteroskedasticity. P-values in brackets. ***, **, * indicates coefficients that are significant to $1 \%, 5 \%$ and $10 \%$ respectively. The regressors are described in Table 2. ${ }^{\mathbf{a}}$ Results for securitizations corresponding to the 2005.012007.06 period.

\section{CONCLUSIONS}

Using securitization transactions in the Spanish market from 1995 to 2010 and an event study methodology, it has been shown that there is empirical evidence that indicates that Spanish banking credit risk securitization announcements generate negative wealth effects for shareholders. This effect, in the analysis by sub-periods, is maintained between 2005 and June 2007, but is insignificant between 1995 and 2004 and between July 2007 and 2010. 
This negative wealth effect is concentrated on the +2 day after the announcement of the securitization operation. The effect does not register prior to this day or immediately afterwards, but occurs on the second day after the announcement.

This analysis shows that the negative wealth effect due to securitization activity in Spain depends on the juncture, and is concentrated the two years immediately prior to the subprime crisis. The analysis also shows that securitization operations are more highly relevant for the small and medium sized originator entities which register a significant negative wealth effect in contrast to the larger entities. Further, the securitized loan only produces a significant negative wealth effect in the case of mortgage collateral. This result demonstrates that the effects of the underlying asset are conditioned by the difference between the risk of the asset and the credit risk of the residual loans portfolio. Mortgage portfolios contain granular collateral which is relatively undiversified. This enables banks to transfer the lower risk tranches while retaining those that are high-risk.

We find that liquidity, solvency and the volume of securitization significantly influences bank share prices. The first two of these have a positive influence. In contrast, the volume of securitization negatively affects share prices.

Our results indicate that shareholders cannot anticipate a decrease in the overall risk-taking of Spanish issuing banks as the result of the securitization of credit risk. Shareholders perceive and value only the direct effect of securitization - not the indirect effect -, which has a positive, significant influence. However, this effect is not strong enough to compensate for the negative variation in prices. This might be because the originator banks in our sample retained the majority of their default risk in the first loss tranche as a sign of quality for investors. The direct effect loses its significance during the years immediately prior to the crisis, exacerbating the negative effect of securitization during this period.

The conclusions obtained in this study are consistent with and substantially improve upon the empirical results of Lockwood et al. (1996) and Thomas (2001) for the U.S. bank market and upon the evidence provided by Franke and Krahnen (2006) for the European bank market (19992002). Udhe et al. (2012) also provide empirical evidence that shows there are negative wealth 
effects caused by credit risk securitization which are time-dependent. Our results are consistent with most of the empirical literature on the subject, but are novel with respect to Spain and differ from those reported by Martinez-Solano et al. (2009) in which a positive wealth effect is recorded for the 1993-2004 period. Other studies such as Thomas (1999) and Higgins and Mason (2004) present positive effects. Thomas (2001) points out that the differences between studies come from the fact that the periods analyzed are different.

This is the first time the wealth effect has been analysed for Spain using the type of collateral, the size of the issuing entity and different sub-periods. To our knowledge, there is no other study that shows how the direct and indirect effects impinge upon the issuing entity's share prices.

The empirical findings presented in this study support current policy and industrial initiatives designed to strengthen the securitization markets, improve the regulation of capital and foment greater responsibility and transparency with respect to securitization activity within Spanish banks and European banks in general. These measures should serve to overcome market frictions and to reestablish a certain confidence in the practice of securitization. In view of the results obtained here, it would seem that progress is being made in this direction given that the securitizations issued after July 2007 do not reflect an impact on share prices.

Finally, it should be stated that this work has certain limitations derived from the elaboration of the data base using securitizations carried out in Spain which has lead us to use continuous stock market quotes and those of the fixed markets, and the cleansing of some of this data as a consequence of the confluence of different events.

\section{REFERENCES}

Abad, P., \& Robles, M. D. (2014). Credit rating agencies and idiosyncratic risk: Is there a linkage? Evidence from the Spanish Market. International Review of Economics \& Finance, Vol. 33, September, 152-171. Allen, F., \& Gale, D. (2006). Systemic risk and regulations. In M. Carey, \& R. M. Stulz (Eds.), The risks of Financial Institutions (pp. 341-376). Chicago: University of Chicago Press.

Arce, O., Ispierto, A., \& Martín, R.. (2012). Hacia mercados secundarios de titulización líquidos y eficientes. Estabilidad Financiera, $\mathrm{N}^{\circ} 22,75-95$, Banco de España. 
Boehmer, E., Musumeci, J., \& Poulsen, A. B. (1991). Event-Study Methodology under Conditions of Event-induced Variance. Journal of Financial Economics, Vol. 30, №. 2, 253-272.

Brown, S. J., \& Warner, J. B. (1985). Using daily stock returns. The case of event studies. Journal of Financial Economics, Vol. 14, №. 1, 3-31.

Calem, P. S., \& Lacour-Little, M. (2003). Risk-based capital requirements for mortgage loans. Journal of Banking and Finance 28, 647-672.

Calmes, C., \& Théoret, R. (2010). The impact of off-balance -sheet activities on banks returns: an application of the ARCH-M to Canadian data. Journal of Banking \& Finance 34 (7), 1719-1728.

Campbell, C. J., Cowan, A. R., \& Salotti, V. (2010). Multi-country event-study methods. Journal of Banking \& Finance 34 (12), 3078-3090.

Carlstrom, C. T., \&. Samoluk, K. A. (1995). Loan Sales as a response to market-based capital constraints. Journal of Banking and Finance, Vol 19, № 3 and 4, 627-46.

Cardone-Riportella, C., Samaniego-Medina, R., \& Trujillo-Ponce, A. (2010). What drives bank securitisation? The Spanish experience. Journal of Banking \& Finance 34, 2639-2651.

Catarineu, E., \& Pérez, D. (2008). La titulización de activos por parte de las entidades de crédito: El modelo español en el contexto internacional y su tratamiento desde el punto de vista de la regulación prudencial. Estabilidad Financiera, № 14, 89-121.

Casu, B., Clare, A., Sarkisyan, A, \& Thomas, S. (2010). Does securitization reduce credit risk taking? Empirical evidence from US bank holding companies. European Journal of Finance, Vol. 17, № 9 \& 10, 769-88.

Cebenoyan, S., \& Strahan, P. E. (2004). Risk management, capital structure and lending at Banks. Journal of Banking and Finance, $\mathrm{Vol} 28, \mathrm{~N}^{\circ} 1,3-31$.

Chen, C. R., Diltz, J. D., Huang, Y., \& Lung, P. P. (2011). Stock and option market divergence in the presence of noisy information. Journal of Banking \& Finance 35, 2001-2020.

Chortareas, G. E., Girardone, C., \& Ventouri, A. (2011). Financial frictions, bank efficiency and risk: Evidence from the Eurozone, Journal of Business Finance and Accounting, Vol 38, № 1 and 2, 259-87.

Corrado, C. J., \&. Zivney, T. L. (1992). The Specification and Power of the Sign Test in Event Study Hypothesis Tests using Daily Stock Returns. Journal of Financial and Quantitative Analysis, Vol. 27, No. 3, 465-78. 
Delis, M. D., Staikouras, C., \& Varlagas, P. (2008). On the measurement of market power in the banking industry. Journal of Business Finance and Accounting, Vol. 35, № 7 and 8, 1023-61.

DeMarzo, P. M. (2005). The Pooling and Tranching of Securities: A model of Informed Intermediation. Review of Financial Studies, 18 (1), 1-35.

Demirgüç-Kunt, A., \& Detragiache, E. (2002). Does deposit insurance increase banking system stability? An empirical investigation. Journal of Monetary Economics, Vol. 49, № 7, 1373-406.

Douglas, W. D., \& Raghuram, G. R. (2009). The Credit Crisis: Conjectures about Causes and Remedies. American Economic Review, 99: 2, 606-610.

Duffie, D. (2007). Innovations in credit risk transfer: Implications for financial stability. BIS Working Papers, $N^{\circ} 255$.

Farhi, E., \& Tirole, J. (2009). Leverage and the central banker's put. American Economic Review, Vol 99, $\mathrm{N}^{\circ} 2,589-93$.

Franke, G., \& Krahnen, J. P. (2006). Default risk sharing between banks and markets: The contribution of collateralized debt obligations. In M. Carey, \& R. M. Stulz (Eds), The Risks of Financial Institutions, (pp. 603-633). Chicago: University of Chicago Press.

Fuentes Egusquiza, I. (2007). La titulización en España: Principales características. Boletín Económico del Banco de España, diciembre, 90-98.

Gasbarro, D., Stevenson, M., Schwebach, R.. G., \& Zumwat, J. K. (2005). The Response of Bank Share Prices to Securitization Announcements. Quarterly Journal of Business, Vol. 4, 1-2, 89-105.

Gorton, G. B., \&. Pennacchi, G. G. (1995). Banks and loan sales: Marketing nonmarketable assets. Journal of Monetary Economics, Vol 35, N 3, 379-401.

Greenbaum, S. I., \&. Thakor, A. V. (1987). Bank funding modes: Securitization versus deposits. Journal of Banking and Finance Vol. 11, № 3, 389-411.

Hänsel, D. N., \& Krahnen, J.P. (2007). Does Credit Securitization Reduce Bank Risk? Evidence from the European CDO Market 29. SSRN working paper. Available at: http://ssrn.com/abstract=967430

Higgins, E. J., \& Mason, J. R. (2004). What is the value of recourse to asset-backed securities? A clinical study of credit card banks. Journal of Banking and Finance 28, 875-899.

Instefjord, N. (2005). Risk and Hedging: Do credit derivates increase bank risk? Evidence from the European CDO market. Journal of Banking \& Finance 29, 2, February, 333-345. doi:10.1016/j.jbankfin.2004.05.008 
Jiangli, W., Pritsker, M., \& Paupach, P. (2007). Banking and Securitization. Working Paper, FDIC (Federal Reserve Board and Deutsche Bundesbank).

Jiangli, W., \& Pritsker, M. (2008). The impacts of securitization on US bank holding companies. Federal Reserve Bank of Chicago Proceedings, May, 377-393.

Keys, B., Mukherjee, T., Seru, A., \& Vig, V. (2010). Did securitization lead to lax screening? Evidence from subprime loans. Quarterly Journal of Economics 125 (1), 307-362.

Kolari, J. W. \& Pynnönen, S. (2010). Even study with cross-sectional correlation of abnormal returns. Review of Financial Studies 23, 3996-4025.

Leland, H. E. (2007). Financial synergies and the optimal scope of the firm: Implications for mergers, spinoffs, and structured finance. Journal of Finance 62, 2, 765-807.

Lockwood, L. J., Rutherford, R.. C., \& Herrera, M. J. (1996). Wealth effects of asset securitization. Journal of Banking \& Finance 20, January, 151-164. doi:10.1016/0378-4266(94)00101-4

Martín-Oliver, A., \& Saurina, J. (2007). Why do Banks Securitize Assets?. Working Paper (Banco de España).

Martínez-Solano, P., Yagüe-Guirao, J., \& López-Martínez, F. (2009). Asset securitization: effects on value of banking institutions. The European Journal of Finance 15, 2, February, 119-136.

Merton, R. C. (1995). Financial innovation and the regulation of financial institutions. Journal of Banking and Finance 19, 3-4, 461-481.

Morales, L., \& Andreosso-O’Callaghan, B. (2014). The global financial crisis: World market or regional contagion effects. International Review of Economics and Finance, 29, January, 108-131.

Nijskens, R., \& Wagner, W. (2011). Credit risk transfer activities and systemic risk: How banks became less risky individually but posed greater risks to the financial system at the same time. Journal of Banking and Finance 35: 1391-1398.

Osborne, D. K., \& Lee, S. (2001). Effects of deposit insurance reform on moral hazard in US banking. Journal of Business Finance and Accounting, Vol. 28, No 7 and 8, 979-92

Peydró, J. L., \& Maddaloni, A. (2010). Bank risk-taking, securitization, supervision, and low interest rates: Evidence from lending standards. ECB Working Paper Series, № 1248.

Purnanandam, A. (2011). Originate to distribute model and the subprime mortgage crisis. Review of Financial Studies, 24 (6), 1881-1915. 
Rosenthal, J. A., \&. Ocampo, J.M. (1988). Analyzing the economic benefits of securitized credit. Journal of Applied Corporate Finance, Vol. 1, No 3, pp. 32-44.

Riddiough, T. J. (1997). Optimal design of asset backed securities. Journal of Financial Intermediation 6, $121-152$

Shin, H. S. (2009). Securitization and Financial Stability. The Economic Journal, 119, 309-332.

Stulz, R. (1990). Managerial discretion and optimal financing policies. Journal of Financial Economics, Vol. 26, $\mathrm{N}^{\mathrm{o}}$ 1, pp. 3-27.

Thomas, H. (1999). A preliminary look at gains from asset securitization. Journal of International Financial Markets, Institutions and Money, 9, 321-333.

Thomas, H. (2001). Effects of asset securitization on seller claimants. Journal of Financial Intermediation, 10, 306-330.

Uhde, A., Farruggio, C., \& Michalak, T. C. (2012). Wealth Effects of Credit Risk Securitization in European Banking. Journal of Business Finance \& Accounting, 39 (1) \& 2, January/March, doi: 10.1111/j.1468-5957.2012.02273.x 
Table 1. Sample characteristics

\begin{tabular}{|c|c|c|c|c|c|c|c|c|c|c|c|c|c|c|c|}
\hline \multicolumn{16}{|c|}{ Distribution by years } \\
\hline 1995 & 1996 & 1997 & 1998 & 1999 & 2000 & 2001 & 2002 & 2003 & 2004 & 2005 & 2006 & 2007 & 2008 & 2009 & 2010 \\
\hline Number & & 1 & 7 & 6 & 4 & 3 & 5 & 5 & 13 & 11 & 21 & 41 & 29 & 14 & 1 \\
\hline Percentage & & 0.62 & 4.32 & 3.70 & 2.47 & 1.85 & 3.09 & 3.09 & 8.02 & 6.79 & 12.96 & 25.31 & 17.90 & 8.64 & 0.62 \\
\hline $\begin{array}{l}\text { Total value of } \\
\text { assets issued } \\
\text { (Millions } € \text { ) }\end{array}$ & & 262.49 & 737.50 & 1947.40 & 969.45 & 1955.84 & 3872.50 & 3870.00 & 12062.00 & 11308.00 & 24240.44 & 47465.17 & 42024.79 & 19656.43 & 1260.00 \\
\hline Percentage & & 0.15 & 0.43 & 1.13 & 0.56 & 1.14 & 2.25 & 2.25 & 7.02 & 6.58 & 14.11 & 27.63 & 24.46 & 11.44 & 0.73 \\
\hline \multicolumn{16}{|c|}{ Distribution by type of collateral (Number) } \\
\hline $\begin{array}{c}199 \\
5\end{array}$ & 1996 & 1997 & 1998 & 1999 & 2000 & 2001 & 2002 & 2003 & 2004 & 2005 & 2006 & 2007 & 2008 & 2009 & 2010 \\
\hline Mortgages & & 1 & 7 & 5 & 3 & 3 & 5 & 2 & 6 & 5 & 7 & 8 & 11 & 4 & 1 \\
\hline Business loans & & & & 1 & 1 & & & 2 & 5 & 4 & 11 & 22 & 9 & 8 & \\
\hline Consumer credit & & & & & & & & 1 & 2 & 2 & 3 & 11 & 9 & 2 & \\
\hline \multicolumn{16}{|c|}{ Distribution by month } \\
\hline January & February & March & April & May & June & July & August & September & October & November & December & & & & \\
\hline Number & 9 & 12 & 14 & 22 & 20 & 12 & 2 & 19 & 25 & 12 & 11 & & & & \\
\hline Percentage & 5.56 & 7.41 & 8.64 & 13.58 & 12.35 & 7.41 & 1.23 & 11.73 & 15.43 & 7.41 & 6.79 & & & & \\
\hline \multicolumn{16}{|c|}{ Distribution by bank } \\
\hline & Number & Percentage & Total & $\begin{array}{l}\text { lue of assets } \\
\text { Millions } \epsilon \text { ) }\end{array}$ & ssued & Mean & $\begin{array}{l}\text { lue of asset } \\
\text { Millions } \epsilon \text { ) }\end{array}$ & issued & & & & & & & \\
\hline Banco de Andalucía & 7 & 4.32 & & 1870.13 & & & 267.16 & & & & & & & & \\
\hline Banco Español de Crédito & 10 & 6.17 & & 13694.00 & & & 1369.40 & & & & & & & & \\
\hline Bankinter & 23 & 14.20 & & 24232.40 & & & 1053.58 & & & & & & & & \\
\hline BBVA & 26 & 16.05 & & 58947.10 & & & 2267.19 & & & & & & & & \\
\hline Banco de Castilla & 6 & 3.70 & & 760.31 & & & 126.71 & & & & & & & & \\
\hline Banco de Crédito Balear & 6 & 3.70 & & 341.52 & & & 56.92 & & & & & & & & \\
\hline Banco de Galicia & 6 & 3.70 & & 693.27 & & & 115.54 & & & & & & & & \\
\hline Banco Guipuzcoano & 13 & 8.02 & & 3049.29 & & & 234.56 & & & & & & & & \\
\hline Banco Pastor & 11 & 6.79 & & 6201.00 & & & 563.72 & & & & & & & & \\
\hline Banco Popular Español & 11 & 6.79 & & 14678.92 & & & 1334.44 & & & & & & & & \\
\hline Banco Sabadell & 13 & 8.02 & & 13780.00 & & & 1060.00 & & & & & & & & \\
\hline Banco Santander & 18 & 11.11 & & 29530.59 & & & 1640.58 & & & & & & & & \\
\hline Banco de Valencia & 6 & 3.70 & & 3342.30 & & & 557.05 & & & & & & & & \\
\hline Banco de Vasconia & 6 & 3.70 & & 691.19 & & & 115.19 & & & & & & & & \\
\hline Total & 162 & & & 171812.00 & & & 1060.56 & & & & & & & & \\
\hline
\end{tabular}


Table 2. Variables and data sources

\begin{tabular}{|c|c|c|}
\hline Variable & Description & Data source \\
\hline Correlation $(\rho)$ & $\begin{array}{l}\text { Correlation between the share } \mathrm{i} \text { and the } \\
\text { market. }\end{array}$ & BME, authors' calc. \\
\hline $\begin{array}{l}\text { Relative standard deviation } \\
\text { (REL_SD) }\end{array}$ & $\begin{array}{l}\text { Ratio of the standard deviation of the returns } \\
\text { of the share } i \text { to standard deviation of the } \\
\text { market return }\end{array}$ & BME, authors' calc. \\
\hline Z-Score (SOL) & $\begin{array}{l}\text { Ratio of the sum of equity capital to total } \\
\text { assets and the ROAA to standard deviation of } \\
\text { ROAA. }\end{array}$ & BankScope, authors' calc. \\
\hline ROAA & $\begin{array}{l}\text { Accounting value of a bank's return on } \\
\text { average assets before taxes. }\end{array}$ & BankScope \\
\hline Capital ratio $(\mathrm{K})$ & $\begin{array}{l}\text { Accounting value of a bank's ratio of equity } \\
\text { to total assets. }\end{array}$ & BankScope \\
\hline $\operatorname{SD}_{\text {ROAA }}(\sigma)$ & $\begin{array}{l}\text { Standard deviation of a bank's ROAA for a } \\
\text { rolling time windows, } 3 \text { years. }\end{array}$ & Authors' calc. \\
\hline $\begin{array}{l}\text { Securitization } \\
\text { (SVOL) }\end{array}$ & $\begin{array}{l}\text { Extent of securitizations issued by a bank } \\
\text { (millions } € \text { ). }\end{array}$ & $\begin{array}{l}\text { CNMV, AIAF and securitization } \\
\text { management companies' web pages }\end{array}$ \\
\hline $\begin{array}{l}\text { Net interest margin } \\
\text { (Netintmargin) }\end{array}$ & $\begin{array}{l}\text { Proxy for the bank's profitability. } \\
\text { Accounting value of a bank's net interest } \\
\text { revenue as a share of its interest-bearing } \\
\text { (total earning) assets. }\end{array}$ & BankScope \\
\hline $\begin{array}{l}\text { Liquid assets } \\
\text { (LIQ) }\end{array}$ & $\begin{array}{l}\text { Proxy for the bank's liquidity. Accounting } \\
\text { value of a bank's liquid assets to its total } \\
\text { assets. }\end{array}$ & BankScope \\
\hline $\begin{array}{l}\text { Impaired loans } \\
\text { (Imploans) }\end{array}$ & $\begin{array}{l}\text { Proxy for the bank's asset quality. } \\
\text { Accounting value of a bank's non- } \\
\text { performing loans to gross loans. }\end{array}$ & BankScope \\
\hline DMORT & $\begin{array}{l}\text { Dummy equal } 1 \text { for mortgage collateral, and } \\
\text { equal } 0 \text { for other collateral }\end{array}$ & \\
\hline
\end{tabular}

